\title{
Rituximab therapy in adults with steroid-dependent nephrotic syndrome
}

\author{
Hongzhen Zhong ${ }^{1}$, Hong-Yan Li², Tianbiao Zhou' ${ }^{1}$, Wenjuan Weng ${ }^{1}$
}

${ }^{1}$ Department of Nephrology, the Second Affiliated Hospital of Shantou University Medical College, Shantou, China

2Department of Nephrology, Huadu District People's Hospital of Guangzhou, Southern Medical University, Guangzhou, China

Submitted: 27 June 2019

Accepted: 25 August 2019

Arch Med Sci

DOI: https://doi.org/10.5114/aoms.2019.88404

Copyright $\odot 2019$ Termedia \& Banach

\section{Abstract}

Introduction: Patients with steroid-dependent nephrotic syndrome (SDNS) suffer frequent relapse with adverse effects caused by long-term prednisolone treatment. Recently, the chimeric monoclonal antibody against the protein CD20 (rituximab - RTX) was observed to be efficacious and safe in the treatment of patients with SDNS. We summarized the scientific literature to evaluate RTX therapy in the clinical management of SDNS.

Material and methods: PubMed, EMBASE, and Cochrane Library databases were investigated from interception to 2019-6-6, without language limitation. The analysis was restricted to adults $\geq 19$ years of age. Data were administered and analyzed through the Review manager 5.3 software.

Results: After RTX treatment, relapse times, prednisolone dose, and proteinuria decreased, whereas serum albumin was increased. The clinical parameters blood pressure and total cholesterol diminished also, whereas bone mineral density was improved. Overall, RTX ameliorated the adverse effects of prednisolone. Moreover, the Th1/Th2 ratio was changed except for the CD19 and CD20 cell counts. Additionally, most of the adverse effects of RTX were mild and well tolerated.

Conclusions: In the studies that we considered, we concluded that RTX treatment was effective and safe in the therapy of patients with SDNS. Nevertheless, more randomized controlled trials are required to explore the mechanism of RTX action and verify its efficacy.

Key words: steroid-dependent nephrotic syndrome, rituximab, efficacy, safety.

\section{Introduction}

Steroid-dependent nephrotic syndrome (SDNS) is a class of refractory nephrotic syndrome. A patient with SDNS relapses during steroid taper or withdrawal. Moreover, maintaining high-dose treatment for long term causes severe immunosuppressive effects [1, 2], and increases morbidity and mortality $[3,4]$. Other side effects caused by steroid treatment such as cushingoid features, hypertension, growth failure, and emotional problems are also reported [5].

Severe proteinuria and hypoproteinemia characterize the nephrotic syndrome, which is common in children and adults [6]. Rituximab (RTX), a chimeric monoclonal anti-CD20 antibody, is used in the treatment of

\author{
Corresponding author: \\ Tianbiao Zhou \\ Department \\ of Nephrology \\ the Second Affiliated \\ Hospital of Shantou \\ University Medical \\ College \\ Shantou, China \\ E-mail: zhoutb@aliyun.com
}


several immune diseases [7-9], and recently it was observed to be efficacious in the treatment of pediatric and adult SDNS [10-15].

To explore the efficacy and safety of RTX treatment in patients with SDNS, we reviewed the literature regarding its therapeutic use in SDNS.

\section{Material and methods}

\section{Literature search}

Search terms were "rituximab" or "anti-CD20 antibodies" and "steroid-dependent nephrotic syndrome" or "SDNS" or "frequently relapsing nephrotic syndrome" or "FRNS". Currently, RTX is permitted only in children with SDNS, so Clinical Trials were waived, and keyword searches were conducted in PubMed, EMBASE and Cochrane Library from interception to 2019-6-6, without language limitation. We considered only adult cases (age $\geq 19$ ). Reference lists of every relevant trial or review article were also searched. Disagreement was resolved through discussion.

\section{Inclusion and exclusion criteria}

Included articles met the following criteria: 1) Diseases: SDNS or FRNS. 2) Treatment: RTX. 3) Patients' age $\geq 19$. Exclusion criteria: 1) Secondary treatment for other systemic diseases; 2) Combined treatment with other immunosuppressive drugs; 3) Patients' age $<19$.

\section{Data extraction}

Data from eligible studies were divided into two parts: 1) Basic information: the first author, publication year, PMID in PubMed, database identification number, number of patients, age of patients, administration of RTX, follow-up; 2) Outcomes data: clinical characterization (relapse, prednisolone dose, serum albumin, proteinuria and serum creatinine), immunological characterization (IgG, CD19 cell count, CD20 cell count, CD4/8 ratio, Th1/2 ratio). Adverse effect ( $A E)$ of prednisolone (body mass index (BMI), total cholesterol, diastolic blood pressure (DBP), systolic blood pressure (SBP), bone mineral density (BMD), and T-score of $B M D)$, and AE of RTX.

\section{Statistical analysis}

Hypoalbuminemia, severe proteinuria, prednisolone dose and frequent relapse were characteristics of SDNS. So, relapse times, prednisolone dose and those laboratory indexes were extracted to estimate the efficacy of RTX in SDNS. Heavy and long-term treatment with prednisolone causes obesity, hyperlipidemia, hypertension and osteoporosis. Thus, we compared the BMI, blood total cholesterol, SBP, DBP, BMD and $T$-score to assess whether RTX reduced the adverse effect of prednisolone in patients with SDNS. RTX is a monoclonal antibody targeting CD20 positive cells. We reported the data regarding the level of IgG, CD19 cell count, CD4/8 cell ratio and Th1/2 cell ratio except CD20 cells to explore the immunological influence of RTX in patients.

Data were extracted to compare the pre- with the post-RTX treatment and management with the Review manager 5.3 software to calculate the mean differences. Data were continuous variables and were expressed as mean \pm standard deviation (SD). Standardized mean difference (SMD) with 95\% confidence intervals were used. We calculated $l^{2}$ to estimate the heterogeneity of the included studies. When $I^{2}<50 \%$, we used a fixed-effects model. In the case of $R \geq 50 \%$ to assume substantial variability, we used a random-effects model. We considered significant those differences with a $p$-value $<0.05$.

\section{Results}

\section{Search results and study characteristics}

Among the 135 abstracts identified, 8 fitted our inclusion criteria with 209 patients and a male/ female ratio of $143 / 66$. The follow-up period was no less than 12 months. RTX was administered in a single dose of $375 \mathrm{mg} / \mathrm{m}^{2}$ at 6-month intervals or $1000 \mathrm{mg}$ (Table I).

\section{Rituximab was effective in the treatment of SDNS}

Four studies [16-19] (102 patients) were included to assess the influence of RTX on disease relapse. The $I^{2}$ was 0 , so a fixed effects model was used. We found a statistically significant difference between pre- and post-RTX treatment relapse in SDNS patients after RTX was administered less frequently (SMD: $-1.96(-2.30,-1.62)$, $p<0.00001$; Figure 1).

Four studies $[16,19-21]$ registered the influence of RTX on prednisolone dose. Since the $l^{2}$ was $50 \%$, moderate heterogeneity existed, and a random effects model was conducted. Total impact was $-2.23(-2.69,-1.77)$ with $p<0.00001$ on the dose of prednisolone, showing statistical significance. So, the dose of prednisolone required was reduced after RTX administration (Figure 1 ).

Six studies [17-22] (173 patients) were included to estimate the influence of RTX on the level of serum albumin. The value of $I^{2}$ was $97 \%$, which showed substantial heterogeneity, then a random effects model was chosen. The SMD was 2.52 $(0.95,4.08)$ with $p=0.002$, which showed that the level of serum albumin between baseline and post-RTX was statistically significant, and the level of serum albumin increased after RTX administration (Figure 1). 
Table I. Basic characteristics of eligible studies

\begin{tabular}{|c|c|c|c|c|c|c|c|}
\hline $\begin{array}{l}\text { Author, } \\
\text { year }\end{array}$ & PMID & Study type & $\begin{array}{l}\text { Patient } \\
\text { (n) }\end{array}$ & $\begin{array}{l}\text { Male/ } \\
\text { female } \\
(n / n)\end{array}$ & $\begin{array}{c}\text { Age } \\
\text { [years] }\end{array}$ & RTX administration & $\begin{array}{l}\text { Follow-up } \\
\text { period } \\
\text { [months] }\end{array}$ \\
\hline $\begin{array}{l}\text { Miyabe } \\
2016\end{array}$ & 26138356 & $\begin{array}{l}\text { Comparative } \\
\text { study }\end{array}$ & 54 & $41 / 13$ & $28.2 \pm 10.4$ & $\begin{array}{l}\text { A single dose of } \\
375 \mathrm{mg} / \mathrm{m}^{2} \mathrm{BSA} \text { at } \\
6 \text {-month interval }\end{array}$ & 24 \\
\hline $\begin{array}{l}\text { Iwabuchi } \\
2018\end{array}$ & 30334956 & $\begin{array}{l}\text { Comparative } \\
\text { study; } \\
\text { observational } \\
\text { study }\end{array}$ & 19 & $12 / 7$ & $36.0 \pm 11.4$ & $\begin{array}{l}375 \mathrm{mg} / \mathrm{m}^{2} \text { of RTX at } \\
6 \text {-month intervals }\end{array}$ & 24 \\
\hline $\begin{array}{l}\text { Takura } \\
2017\end{array}$ & 28387313 & $\begin{array}{l}\text { Prospective } \\
\text { study }\end{array}$ & 30 & $21 / 9$ & $29.1 \pm 11.4$ & $\begin{array}{c}375 \mathrm{mg} / \mathrm{m}^{2} \text { body } \\
\text { surface area once } \\
\text { weekly for four weeks }\end{array}$ & 24 \\
\hline $\begin{array}{l}\text { Takei } \\
2013\end{array}$ & 23239834 & $\begin{array}{l}\text { Prospective } \\
\text { study }\end{array}$ & 25 & $19 / 6$ & $30 \pm 12$ & $\begin{array}{l}375 \mathrm{mg} / \mathrm{m}^{2} \text { of RTX at } \\
6 \text {-month intervals }\end{array}$ & 12 \\
\hline $\begin{array}{l}\text { Iwabuchi } \\
2014\end{array}$ & 25546674 & $\begin{array}{l}\text { Prospective } \\
\text { cohort study }\end{array}$ & 25 & $21 / 4$ & $30.1 \pm 11.9$ & $\begin{array}{l}375 \mathrm{mg} / \mathrm{m}^{2} \text { of RTX at } \\
6 \text {-month intervals }\end{array}$ & 24 \\
\hline $\begin{array}{l}\text { DaSilva } \\
2017\end{array}$ & 28534103 & $\begin{array}{l}\text { Retrospective } \\
\text { study }\end{array}$ & 28 & $16 / 12$ & $37 \pm 15$ & $\begin{array}{l}\text { Infusions of rituximab } \\
1000 \mathrm{mg} \text { or } 375 \mathrm{mg} / \mathrm{m}^{2}\end{array}$ & $31 \pm 26$ \\
\hline $\begin{array}{l}\text { Ruggenenti } \\
2014\end{array}$ & 24480824 & $\begin{array}{l}\text { Multicenter } \\
\text { clinical study }\end{array}$ & 20 & $10 / 10$ & $\begin{array}{c}34.3 \\
(22.7-47.4)\end{array}$ & $\begin{array}{c}375 \mathrm{mg} / \mathrm{m}^{2} \text { of rituximab } \\
\text { was infused according } \\
\text { to circulating B cells }\end{array}$ & 12 \\
\hline $\begin{array}{l}\text { Katsuno } \\
2019\end{array}$ & 30121802 & $\begin{array}{l}\text { Retrospective } \\
\text { cohort study }\end{array}$ & 8 & $3 / 5$ & $40.8 \pm 11.5$ & $1137.5 \pm 866.7 \mathrm{mg}$ & $\begin{array}{c}13.9 \\
(11.6-20.0)\end{array}$ \\
\hline
\end{tabular}

Four studies [17, 19-21] (134 patients) were considered to investigate the effect of RTX on proteinuria. Since proteinuria disappeared after RTX treatment in two studies $[17,19]$, these data could not be pooled for analysis. Proteinuria was $\leq 0.5$ $\mathrm{g} /$ day, which was defined as a complete response in the treatment of nephrotic syndrome, and the level of proteinuria met the criteria in the other two studies [20, 21]. So, proteinuria was lower after RTX treatment (Figure 1).

Six studies [17-22] could evaluate the role of RTX in the change of serum creatinine. The value of $I^{2}=0 \%$ indicates no heterogeneity, so a fixed effects model was used. The SMD was $-0.13(-0.34$, 0.09 ) with $p=0.25$, which was more than 0.5 . No statistically significant difference was detected, so the level of serum creatinine was undifferentiated between post-RTX and baseline (Figure 1).

\section{Rituximab reduced the adverse effect of prednisolone}

Three $[18,20,22]$ of the eight quality studies were associated with BMI. Since no heterogeneity was found $\left(I^{2}=0 \%\right)$, we applied a fixed-effects model. The BMI after RTX treatment was similar to baseline $(\mathrm{SMD}=0.01(-0.29,0.32) ; p=0.93)$ (Figure 2).

Five studies [17, 18, 20-22] assessed the effect of RTX in the SBP and DBP. Both $l^{2}=0 \%$, no obvious heterogeneity was shown, so a fixed effects model was conducted. The SMDs were -0.54 $(-0.79,-0.29)$ with $p<0.0001$ and $-0.48(-0.73$,
-0.24) with $p=0.0001$ for SBP and DBP, respectively. Both had statistical significance, so after RTX administration, SBP and DBP were lower than baseline (Figure 2).

The influence of RTX on the total cholesterol was assessed in five studies [17, 19-22]. Large heterogeneity was observed in the included studies $\left(1^{2}=\right.$ $67 \%)$, so a random effects model was used. There was a statistically significant difference between post-RTX and baseline (SMD was -0.97 ( -1.40 , -0.54) with $p<0.00001)$, showing that total cholesterol was lower after RTX administration (Figure 2).

The impact of RTX administration was assessed by BMD $[17,19,20]$ and T-score of BMD [18-20] in three studies. Both heterogeneities were large, for $I^{2}=92 \%$ and $I^{2}=98 \%$ in BMD and $T$-score of $B M D$, and random effects models were used. The SMDs were $1.26(0.19,2.34), p=0.02$ and 1.26 $(-0.94,3.46), p=0.26$ respectively. Statistical significance was observed in BMD but not $T$-score of $\mathrm{BMD}$; the level of BMD increased after RTX was administered but not T-score of BMD (Figure 2).

\section{Some immunological indexes were changed after RTX was administered}

Four studies [17-20] evaluated the change of IgG. Overall, the $l^{2}$ was $97 \%$, which showed substantial heterogeneity, so a random effects model was conducted. The result of pooled data was 2.54 $(0.53,4.55)$ with $p=0.01$, showing statistical significance for IgG levels (Figure 3). 
Compare in relapse times

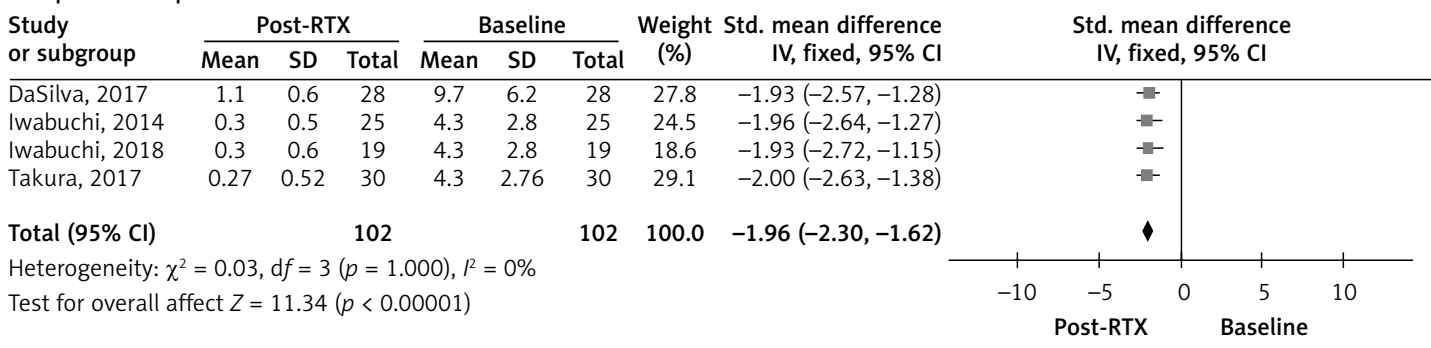

Compare in prednisolone dose

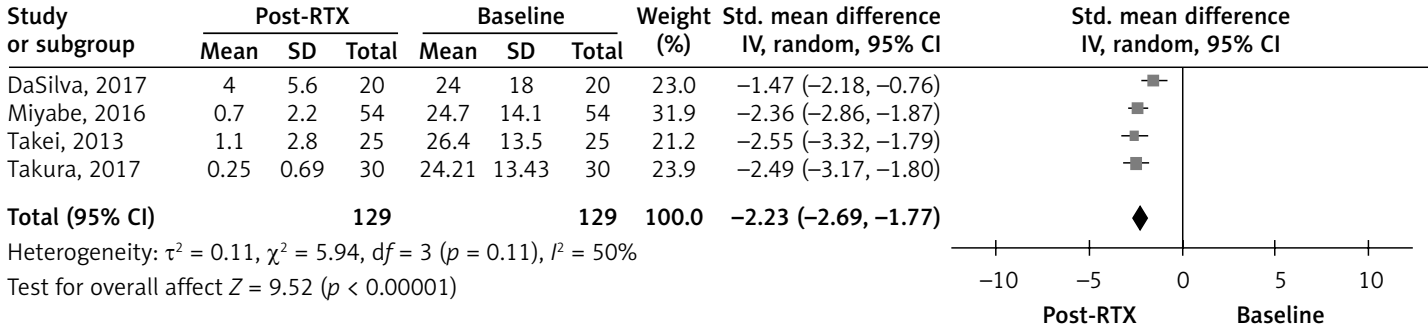

Compare of serum albumin

\begin{tabular}{|c|c|c|c|c|c|c|c|c|c|c|c|c|}
\hline \multirow{2}{*}{$\begin{array}{l}\text { Study } \\
\text { or subgroup }\end{array}$} & \multicolumn{3}{|c|}{ Post-RTX } & \multicolumn{3}{|c|}{ Baseline } & \multirow{2}{*}{$\begin{array}{l}\text { Weight } \\
\text { (\%) }\end{array}$} & \multirow{2}{*}{$\begin{array}{l}\text { Std. mean difference } \\
\text { IV, random, } 95 \% \mathrm{CI}\end{array}$} & \multirow{2}{*}{\multicolumn{4}{|c|}{$\begin{array}{l}\text { Std. mean difference } \\
\mathrm{IV} \text {, random, } 95 \% \mathrm{Cl}\end{array}$}} \\
\hline & Mean & SD & Total & Mean & SD & Total & & & & & & \\
\hline Iwabuchi, 2014 & 4.6 & 0.3 & 25 & 3.6 & 0.8 & 25 & 16.9 & $1.63(0.98,2.28)$ & & & $-\frac{1}{4}$ & \\
\hline Iwabuchi, 2018 & 4.57 & 0.39 & 19 & 3.6 & 0.95 & 19 & 16.8 & $1.31(0.60,2.02)$ & & & - & \\
\hline Miyabe, 2016 & 4.6 & 0.1 & 54 & 3.7 & 0.08 & 54 & 15.3 & $9.87(8.48,11.26)$ & & & & $\rightarrow-$ \\
\hline Ruggenenti, 2014 & 4 & 0.69 & 20 & 3.86 & 0.56 & 20 & 17.0 & $0.22(-0.40,0.84)$ & & & - & \\
\hline Takei, 2013 & 4.2 & 0.3 & 25 & 3.4 & 0.8 & 25 & 17.0 & $1.30(0.69,1.92)$ & & & 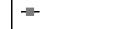 & \\
\hline Takura, 2017 & 4.6 & 0.3 & 30 & 3.6 & 0.9 & 30 & 17.0 & $1.47(0.90,2.05)$ & & & - & \\
\hline Total $(95 \% \mathrm{Cl})$ & & & 173 & & & 173 & 100.0 & $2.52(0.90,2.05)$ & & & & \\
\hline \multirow{2}{*}{\multicolumn{9}{|c|}{$\begin{array}{l}\text { Heterogeneity: } \tau^{2}=3.68, \chi^{2}=155.81, \mathrm{~d} f=5(p<0.00001), I^{2}=97 \% \\
\text { Test for overall affect } Z=3.14(p=0.002)\end{array}$}} & -10 & -5 & 0 & 10 \\
\hline & & & & & & & & & & Post-RTX & Baseline & \\
\hline
\end{tabular}

Compare of proteinuria

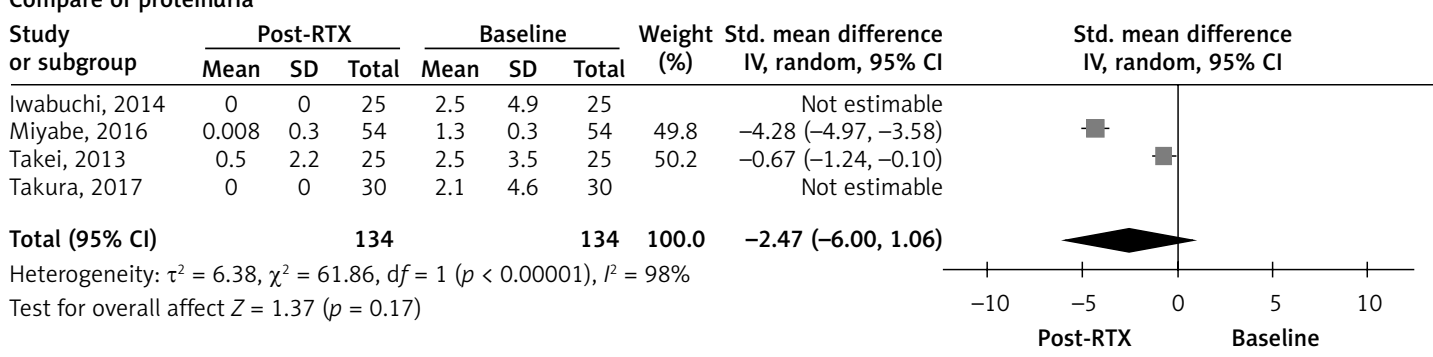

Compare of serum creatinine

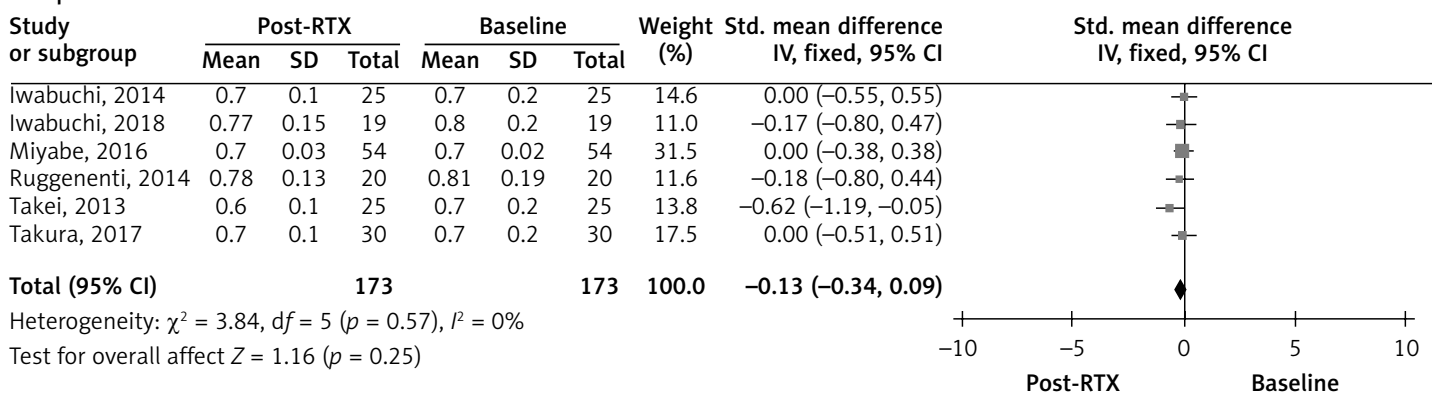

Figure 1. Efficacy of rituximab in SDNS

Three studies $[17,19,20]$ were included to analyze the change of CD20 and CD19 cells. Both $l^{2}$ values $(99 \%)$ justify the random-effects model. The pooled results were $-4.90(-8.88,-0.93)$ with $p=0.02$ and $-4.52(-8.42,-0.63)$ with $p=0.02$ respectively, showing statistically significant differ- ences, and CD20 and CD19 cell counts were lower than baseline, as expected (Figure 3).

Four studies [17-20] were about the change of CD4/8 after RTX was administered. The $l^{2}$ was $97 \%$, which means substantial heterogeneity, and a random-effects model was applicable. The 
Change in BMI

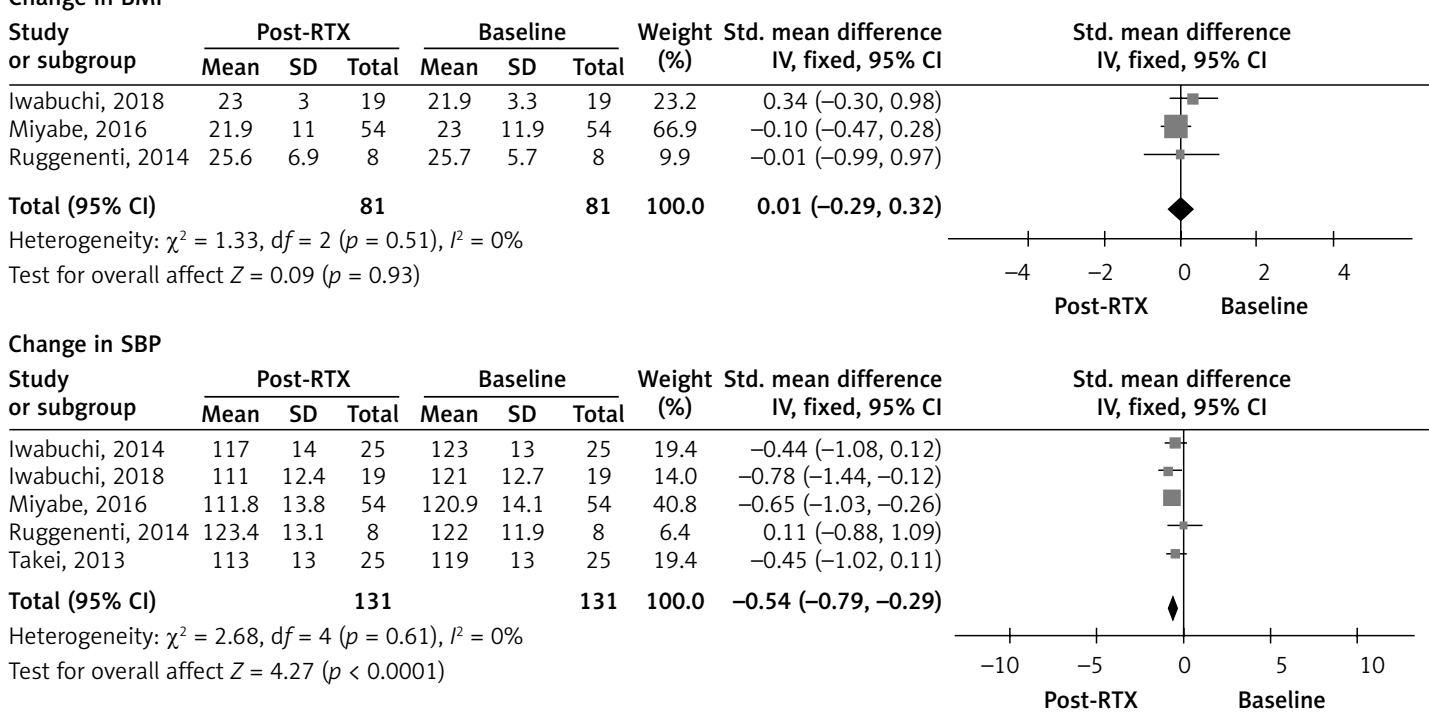

Change in DBP

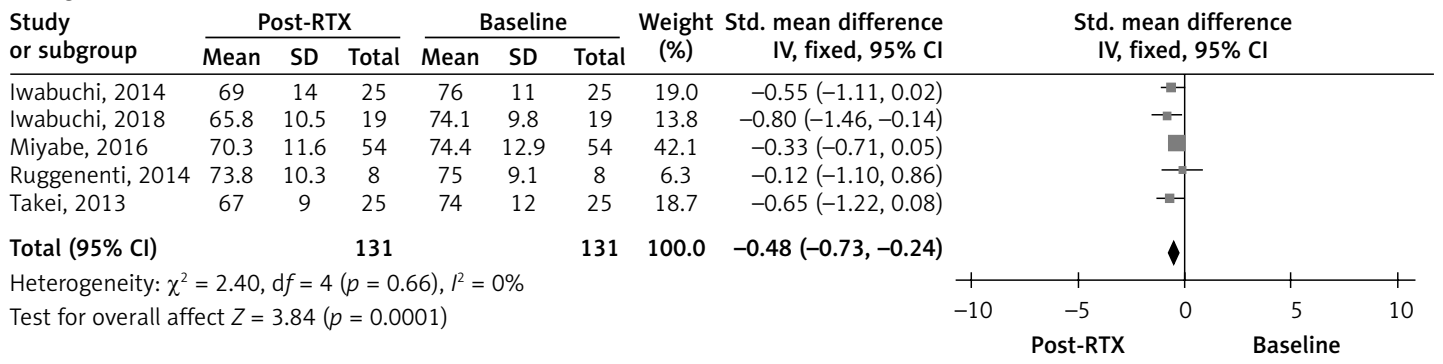

Change in total cholesterol

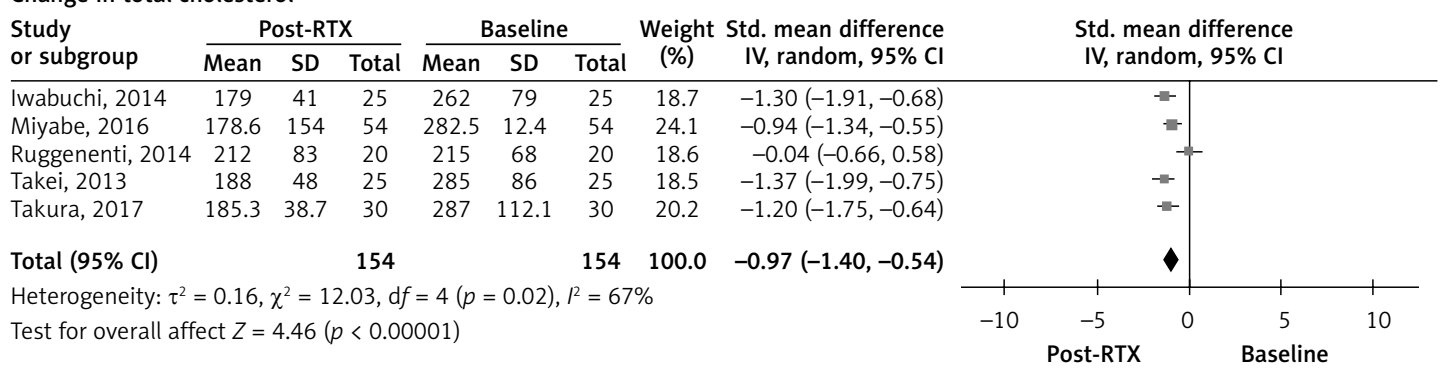

Change in BMD

\begin{tabular}{|c|c|c|c|c|c|c|c|c|c|c|c|c|}
\hline \multirow{2}{*}{$\begin{array}{l}\text { Study } \\
\text { or subgroup }\end{array}$} & \multicolumn{3}{|c|}{ Post-RTX } & \multicolumn{3}{|c|}{ Baseline } & \multirow{2}{*}{$\begin{array}{l}\text { Weight } \\
\text { (\%) }\end{array}$} & \multirow{2}{*}{$\begin{array}{l}\text { Std. mean difference } \\
\text { IV, random, } 95 \% \mathrm{Cl}\end{array}$} & \multirow{2}{*}{\multicolumn{3}{|c|}{$\begin{array}{l}\text { Std. mean difference } \\
\text { IV, random, } 95 \% \mathrm{CI}\end{array}$}} & \\
\hline & Mean & SD & Total & Mean & SD & Total & & & & & & \\
\hline Iwabuchi, 2014 & 0.95 & 0.1 & 25 & 0.84 & 0.2 & 25 & 32.9 & $0.68(0.11,1.26)$ & & & FE- & \\
\hline Miyabe, 2016 & 0.9 & 0.03 & 54 & 0.83 & 0.03 & 54 & 33.7 & $2.32(1.83,2.81)$ & & & 든 & \\
\hline Takura, 2017 & 0.94 & 0.13 & 30 & 0.83 & 0.15 & 30 & 33.4 & $0.77(0.25,1.30)$ & & & $=$ & \\
\hline Total $(95 \% \mathrm{Cl})$ & & & 109 & & & 109 & 100.0 & $1.260 .19,2.34)$ & & & & \\
\hline \multirow{2}{*}{\multicolumn{9}{|c|}{ Heterogeneity: $\tau^{2}=0.83, \chi^{2}=24.69, \mathrm{~d} f=2(p<0.00001), L^{2}=92 \%$}} & 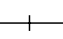 & & & 1 \\
\hline \multirow{2}{*}{\multicolumn{9}{|c|}{ Test for overall affect $Z=2.31(p=0.02)$}} & -10 & -5 & 5 & 10 \\
\hline & & & & & & & & & & Post-RTX & Baselir & \\
\hline
\end{tabular}

$T$-score of BMD

\begin{tabular}{|c|c|c|c|c|c|c|c|c|c|}
\hline \multirow{2}{*}{$\begin{array}{l}\text { Study } \\
\text { or subgroup }\end{array}$} & \multicolumn{3}{|c|}{ Post-RTX } & \multicolumn{3}{|c|}{ Baseline } & \multirow{2}{*}{$\begin{array}{l}\text { Weight } \\
\text { (\%) }\end{array}$} & \multirow{2}{*}{$\begin{array}{l}\text { Std. mean difference } \\
\text { IV, random, } 95 \% \mathrm{Cl}\end{array}$} & \multirow{2}{*}{$\begin{array}{l}\text { Std. mean difference } \\
\text { IV, random, } 95 \% \mathrm{CI}\end{array}$} \\
\hline & $\overline{\text { Mean }}$ & SD & Total & Mean & SD & Total & & & \\
\hline Iwabuchi, 2014 & 0.85 & 1.08 & 19 & 1.56 & 1.6 & 19 & 33.2 & $-0.51(-1.16,0.14)$ & -7 \\
\hline Miyabe, 2016 & -1.1 & 0.2 & 54 & -1.8 & 0.2 & 54 & 33.3 & $3.48(2.87,4.08)$ & -1 \\
\hline Takura, 2017 & -0.73 & 0.78 & 30 & -1.65 & 1.38 & 30 & 33.5 & $0.81(0.28,1.34)$ & - \\
\hline Total $(95 \% \mathrm{Cl})$ & & & 103 & & & 103 & 100.0 & $1.26(-0.94,3.46)$ & \\
\hline \multicolumn{9}{|c|}{ Heterogeneity: $\tau^{2}=3.69, \chi^{2}=83.08, \mathrm{~d} f=2(p<0.00001), I^{2}=98 \%$} & \\
\hline \multicolumn{9}{|c|}{ Test for overall affect $Z=1.12(p=0.26)$} & $\begin{array}{lllll}-4 & -2 & 0 & 2 & 4\end{array}$ \\
\hline
\end{tabular}

Figure 2. Impact of RTX on the adverse effects of prednisolone

$B M I$ - body mass index, SBP - systolic blood pressure, DBP - diastolic blood pressure, BMD - bone mineral density. 
Change in the level of IgG

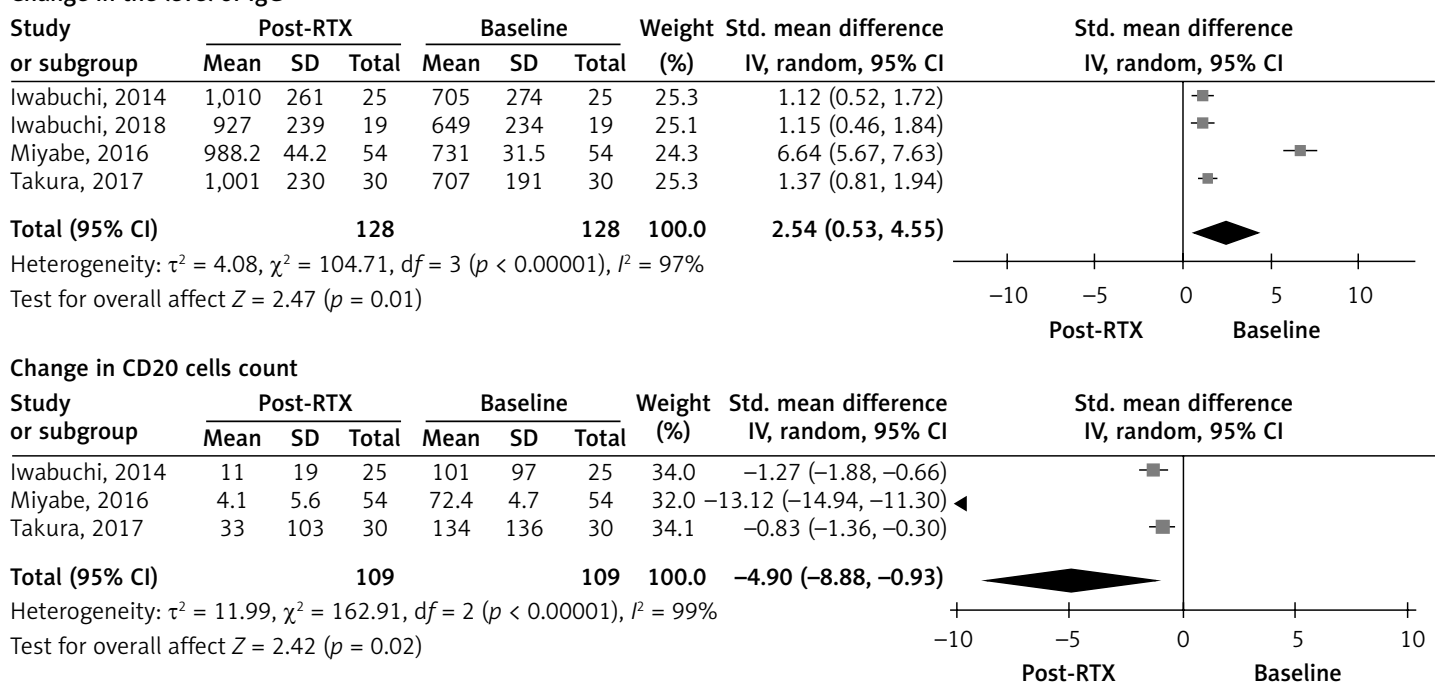

Change in CD19 cells count

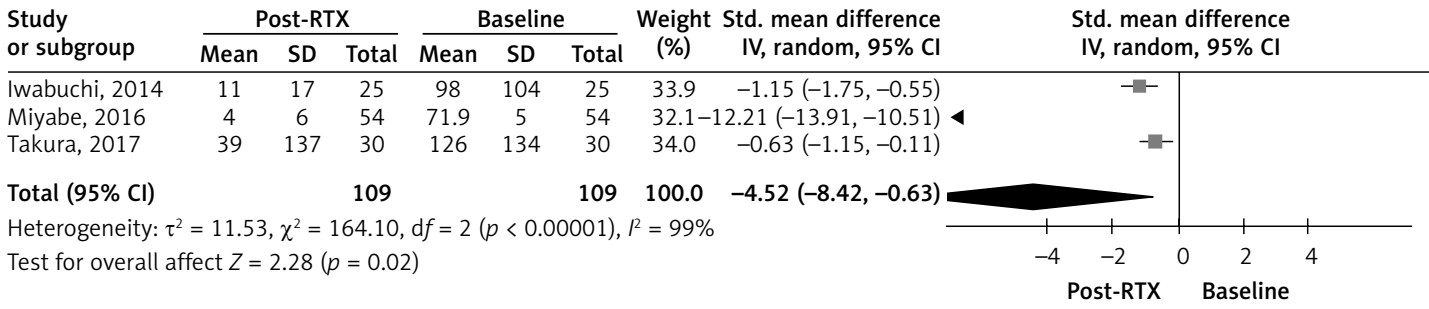

Change in CD4/8 ratio

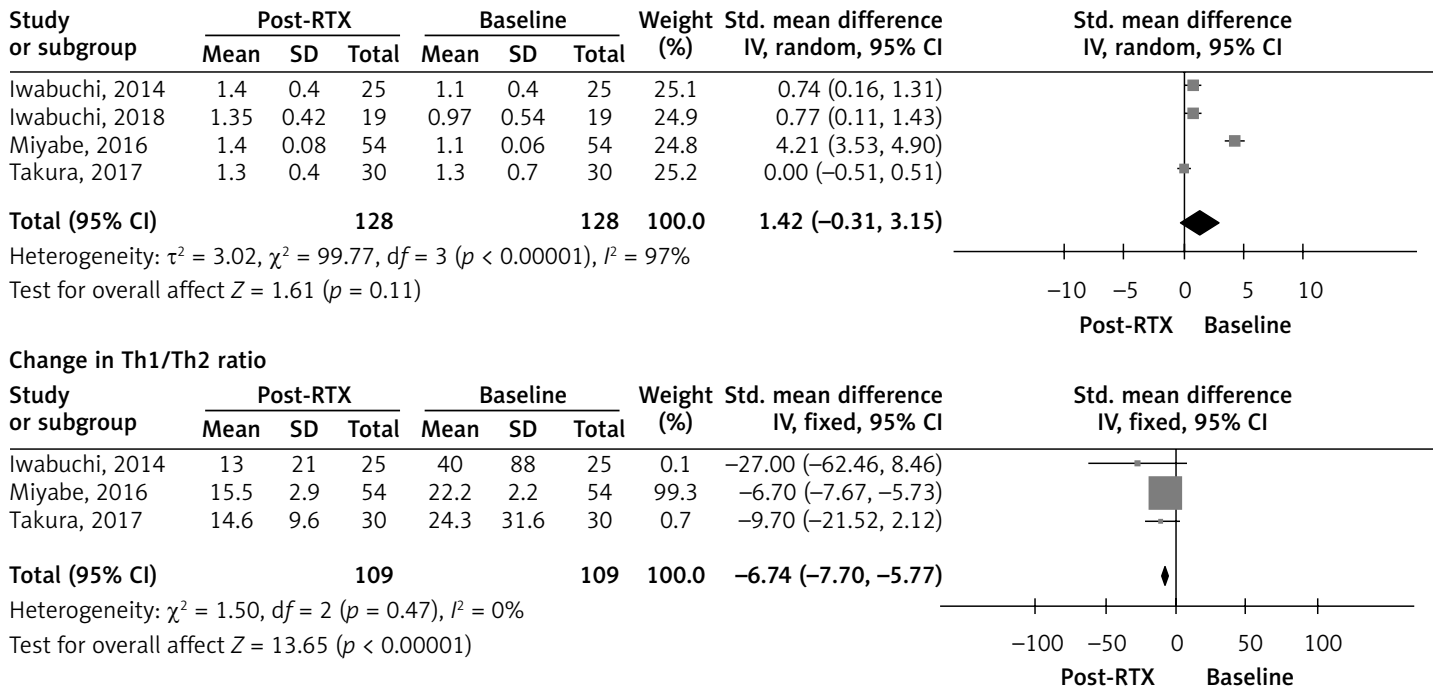

Figure 3. Change of immunological indexes after RTX was administered

pooled result was $1.42(-0.31,3.15)$ with $p=0.11$, and no statistically significant difference was observed. CD4/8 ratio was similar to baseline after RTX treatment (Figure 3).

The effect of RTX on the change of Th1/Th2 ratio was favorable in three studies $[17,19,20] . I^{2}=0 \%$, no obvious heterogeneity was detected, and a fixed-effects model was conducted. The result of pooled data was $-6.74(-7.70,-5.77)$ with $p<$ 0.00001 , and a statistically significant difference was observed between baseline and post-RTX.
Th1/Th2 ratio was lower after RTX was administered (Figure 3).

\section{Adverse effects of rituximab}

The AEs $[16-18,21]$ of RTX are summarized in Table II. The most common adverse effect was infusion reaction, which occurs within $24 \mathrm{~h}$ after RTX administration. The long-term AEs were referable to hematologic reactions, such as leukopenia, neutropenia and agranulocytosis. Those AEs were mild, reversible or curable. 
Table II. Adverse effects of rituximab

\begin{tabular}{|c|c|c|c|}
\hline Adverse effects & Clinical symptoms & Time to event & Treatment and results \\
\hline $\begin{array}{l}\text { Infusion } \\
\text { reactions }\end{array}$ & $\begin{array}{c}\text { Chills, cough, } \\
\text { headache, } \\
\text { hiccough, nausea, } \\
\text { itching, pruritus, } \\
\text { skin rash }\end{array}$ & Within $24 \mathrm{~h}$ after infusion & $\begin{array}{c}\text { Disappeared without treatment or } \\
\text { with a reduction of the infusion } \\
\text { speed }\end{array}$ \\
\hline $\begin{array}{l}\text { Flu-like } \\
\text { reactions }\end{array}$ & $\begin{array}{l}\text { Chills, headache, } \\
\text { nausea, } \\
\text { pharyngalgia, } \\
\text { pyrexia }\end{array}$ & Shortly after RTX infusion & $\begin{array}{l}\text { Improved with betamethasone or } \\
\text { reduction of the rate of RTX infusion }\end{array}$ \\
\hline Exanthema & $\begin{array}{l}\text { A fixed drug } \\
\text { eruption on the } \\
\text { trunk }\end{array}$ & $\begin{array}{l}\text { Immediately after the start of } \\
\text { administration of RTX }\end{array}$ & Improved with betamethasone \\
\hline $\begin{array}{l}\text { Cardiovascular } \\
\text { reactions }\end{array}$ & $\begin{array}{l}\text { Hypotension, sinus } \\
\text { tachycardia, sinus } \\
\text { bradycardia }\end{array}$ & During RTX infusion & $\begin{array}{l}\text { Improved following treatment with } \\
\text { betamethasone or reduction of the } \\
\text { rate of rituximab infusion }\end{array}$ \\
\hline $\begin{array}{l}\text { Hematologic } \\
\text { reactions }\end{array}$ & $\begin{array}{l}\text { Leukopenia, } \\
\text { neutropenia, } \\
\text { agranulocytosis }\end{array}$ & $\begin{array}{l}\text { 1) Neutropenia and leukopenia } \\
\text { occurred at } 1 \text { month or } 9 \text { months } \\
\text { from the baseline } \\
\text { 2) Agranulocytosis occurred } \\
\text { at } 11 \text { months from the baseline }\end{array}$ & $\begin{array}{l}\text { 1) Neutropenia and leukopenia } \\
\text { recovered without any treatment } \\
\text { within } 1 \text { month or } 3 \text { months later } \\
\text { 2) Agranulocytosis improved with } \\
\text { G-CSF administration }\end{array}$ \\
\hline
\end{tabular}

RTX - rituximab, G-CSF - granulocyte colony-stimulating factor.

\section{Discussion}

Treatment of steroid-dependent nephrotic syndrome usually involves steroids accompanied by a broad array of immunosuppressants. The most commonly used immunosuppressive drugs are calcineurin inhibitors, alkylating agents, and antiproliferative immunosuppressants. However, while alkylating agents and anti-proliferative immunosuppressants had compromised defense against viruses and malignancy [23], calcineurin inhibitors cause significant nephrotoxicity [24]. In our meta-analysis, we found RTX effective in the treatment of SDNS by reducing relapse, prednisolone dose, and proteinuria, increasing the level of albumin and having no impact on the serum creatinine. RTX was also able to reduce total cholesterol and blood pressure, and increase serum IgG. RTX alleviated some side-effects of prednisolone, by the reduction of prednisolone dose, and ameliorating the immune response and the lipid metabolism [18]. Ruggenenti et al. [22] also found that RTX treatment benefited blood pressure in pediatric cases. We confirmed some studies that found RTX able to improve patients' BMD [17, 20, 21]. However, the T-score of BMD failed to show any significant difference. Each diagnostic model had certain limitations, and better diagnostic criteria are required. Moreover, the heterogeneity we found in some studies prevented us from conducting a more robust analysis.

RTX reduced autoantibody levels [25] and ameliorated chronic inflammatory diseases mediated by $T$ and B cells [26]. Kamburova et al. [27] found that RTX induces stronger T-cell proliferation (es- pecially Th2-like cells) by B cell stimulation when compared to untreated patients. This partially explains our finding that the Th1/Th2 ratio was lower after RTX administration.

RTX depletes B cells through antibody-dependent cellular cytotoxicity, complement-dependent cytotoxicity, and apoptosis [28, 29], which determine the therapeutic use in malignant B-cell lymphoma [30], and the reduced auto-antibodies in various autoimmune disorders [31, 32]. Moreover, $\mathrm{B}$ cells had an additional role in producing permeability factors with T cells, which provided a rationale for RTX therapy [33]. Interestingly, Fornoni et al. [34] found that RTX prevents the disruption of podocyte apoptosis and actin cytoskeleton through the phosphodiesterase acid-like 3b. All of these data along with our results demonstrate the efficacy of RTX in the treatment of SDNS.

There are some limitations of our analysis. First, the studies included were not randomized controlled trials. Kamburova et al. [35] demonstrated the effect of RTX on the immune response not only through B cell depletion, but also through the cellular functions of the remaining B cells. Thus, the efficacy of RTX might not be as optimistic as we observed. Second, compared with baseline condition, it whittled down self-healing capacity, but it cab eliminate individual difference at the extreme. Third, Munyentwali et al. [15] observed that the relapse of steroid-dependent minimal change disease usually occurred after the reappearance of CD19 cells. Unfortunately, there are no further analyses of the temporal relations between relapse times and CD19 cell count. 
In conclusion, so far, RTX has proved to be an effective and well-tolerated drug for the treatment of SDNS. However, more studies are needed to better evaluate its efficacy, long-term safety and mechanism of action.

\section{Acknwoledgments}

Hongzhen Zhong, Hong-Yan Li and Tianbiao Zhou, should be regarded as joint first authors.

This study was supported by Guangzhou Medical Key Discipline Construction Project (20172019).

\section{Conflict of interest}

The authors declare no conflict of interest.

\section{References}

1. Chen YL, Chen JH. Approach of influence factors on infectious complications in patients with primary nephrotic syndrome. J Zhejiang Univ Med Sci 2003; 32: 145-8.

2. Ogi M, Yokoyama $\mathrm{H}$, Tomosugi $\mathrm{N}$, et al. Risk factors for infection and immunoglobulin replacement therapy in adult nephrotic syndrome. Am J Kidney Dis 1994; 24 . 427-36.

3. McDonough AK, Curtis JR, Saag KG. The epidemiology of glucocorticoid-associated adverse events. Curr Opin Rheumatol 2008; 20: 131-7.

4. Cutolo M, Seriolo B, Pizzorni C, et al. Use of glucocorticoids and risk of infections. Autoimmun Rev 2008; 8 153-5.

5. Bagga A, Ali U, Banerjee S, et al. Management of steroid sensitive nephrotic syndrome: revised guidelines. Indian Pediatr 2008; 45: 203-14

6. Mahalingasivam V, Booth J, Sheaff M, Yaqoob M. Nephrotic syndrome in adults. Acute Med 2018; 17: 36-43.

7. Tlustochowicz M, Sliwczynski AM, Brzozowska M, Teter Z, Marczak M. Sequentiality of treatment in the rheumatoid arthritis drug programme in the years 2009-2014 Arch Med Sci 2018; 14: 569-71

8. Zhong Z, Li H, Zhong H, Zhou T. Clinical efficacy and safety of rituximab in lupus nephritis. Drug Design Developm Ther 2019; 13: 845-56.

9. Fervenza FC, Appel GB, Barbour SJ, et al. Rituximab or cyclosporine in the treatment of membranous nephropathy. N Engl J Med 2019; 381: 36-46.

10. Cortazar FB, Rosenthal J, Laliberte K, Niles JL. Continuous B-cell depletion in frequently relapsing, steroid-dependent and steroid-resistant nephrotic syndrome. Clin Kidney I 2019; 12: 224-31.

11. Bagga A, Sinha A, Moudgil A. Rituximab in patients with the steroid-resistant nephrotic syndrome. N Engl J Med 2007; 356: 2751-2.

12. Ahmed MS, Wong CF. Rituximab and nephrotic syndrome: a new therapeutic hope? Nephrol Dialysis Transplant 2008; 23: 11-7.

13. Solomon N, Lalayiannis AD. Rituximab is more effective than tacrolimus in steroid-dependent nephrotic syndrome. Arch Dis Child Educ Pract Ed 2019 Feb 1. Pii: edpract-2018-316537.

14. Ravani P, Rossi R, Bonanni A, et al. Rituximab in children with steroid-dependent nephrotic syndrome: a multicenter, open-label, noninferiority, randomized controlled trial. J Am Soc Nephrol 2015; 26: 2259-66.
15. Munyentwali H, Bouachi K, Audard V, et al. Rituximab is an efficient and safe treatment in adults with steroid-dependent minimal change disease. Kidney Int 2013; 83: 511-6.

16. DaSilva I, Huerta A, Quintana L, et al. Rituximab for steroid-dependent or frequently relapsing idiopathic nephrotic syndrome in adults: a retrospective, multicenter study in Spain. BioDrugs 2017; 31: 239-49.

17. Iwabuchi Y, Takei T, Moriyama T, Itabashi M, Nitta K. Long-term prognosis of adult patients with steroid-dependent minimal change nephrotic syndrome following rituximab treatment. Medicine 2014; 93: e300.

18. Iwabuchi Y, Miyabe Y, Makabe S, et al. Comparison of the response of frequently relapsing steroid-dependent minimal change nephrotic syndrome to rituximab therapy between childhood-onset and adult-onset disease. Medicine 2018; 97: e12704.

19. Takura T, Takei T, Nitta K. Cost-effectiveness of administering rituximab for steroid-dependent nephrotic syndrome and frequently relapsing nephrotic syndrome: a preliminary study in Japan. Sci Rep 2017; 7: 46036.

20. Miyabe Y, Takei T, Iwabuchi Y, Moriyama T, Nitta K. Amelioration of the adverse effects of prednisolone by rituximab treatment in adults with steroid-dependent minimal-change nephrotic syndrome. Clin Exp Nephrol 2016; 20: 103-10.

21. Takei T, Itabashi M, Moriyama T, et al. Effect of singledose rituximab on steroid-dependent minimal-change nephrotic syndrome in adults. Nephrol Dialysis Transplant 2013; 28: 1225-32.

22. Ruggenenti P, Ruggiero B, Cravedi PV, et al. Rituximab in steroid-dependent or frequently relapsing idiopathic nephrotic syndrome. J Am Soc Nephrol 2014; 25: 850-63.

23. Niaudet P. Long-term outcome of children with steroid-sensitive idiopathic nephrotic syndrome. Clin J Am Soc Nephrol 2009; 4: 1547-8.

24. Gaston RS. Chronic calcineurin inhibitor nephrotoxici ty: reflections on an evolving paradigm. Clin J Am Soc Nephrol 2009; 4: 2029-34.

25. Dorner T, Isenberg D, Jayne D, Wiend H, Zillikens D, Burmester G. Current status on B-cell depletion therapy in autoimmune diseases other than rheumatoid arthritis. Autoimmun Rev 2009; 9: 82-9.

26. Thurlings RM, Vos K, Wijbrandts CA, Zwinderman $A H$ Gerlag DM, Tak PP. Synovial tissue response to rituximab: mechanism of action and identification of biomarkers of response. Ann Rheumat Dis 2008; 67: 917-25.

27. Kamburova EG, Koenen HJ, Boon L, Hilbrands LB, Joos ten I. In vitro effects of rituximab on the proliferation, activation and differentiation of human B cells. Am Transplant 2012; 12: 341-50.

28. Chow KU, Sommerlad WD, Boehrer S, et al. Anti-CD20 antibody (IDEC-C2B8, rituximab) enhances efficacy of cytotoxic drugs on neoplastic lymphocytes in vitro: role of cytokines, complement, and caspases. Haematologica 2002; 87: 33-43.

29. Glennie MJ, French RR, Cragg MS, Taylor RP. Mechanisms of killing by anti-CD20 monoclonal antibodies. Mol Immunol 2007; 44: 3823-37.

30. Pescovitz MD. Rituximab, an anti-cd20 monoclonal antibody: history and mechanism of action. Am J Transplant 2006; 6: 859-66.

31. Anolik JH, Barnard J, Cappione A, et al. Rituximab improves peripheral B cell abnormalities in human systemic lupus erythematosus. Arthritis Rheum 2004; 50: 3580-90.

32. Leandro MJ, Cambridge G, Ehrenstein MR, Edwards JC. Reconstitution of peripheral blood B cells after deple- 
tion with rituximab in patients with rheumatoid arthritis. Arthritis Rheum 2006; 54: 613-20.

33. Matto M, Raunio AR, Postila V, Huttunen K, Hirvonen MR, Pelkonen J. Human $B$ cells and macrophages cooperate in T-cell-independent type 2 response. Scand J Immunol 2008; 67: 209-17.

34. Fornoni A, Sageshima J, Wei C, et al. Rituximab targets podocytes in recurrent focal segmental glomerulosclerosis. Sci Transl Med 2011; 3: 85ra46.

35. Kamburova EG, Koenen HJ, Borgman KJ, ten Berge IJ, Joosten I, Hilbrands LB. A single dose of rituximab does not deplete B cells in secondary lymphoid organs but alters phenotype and function. Am J Transpl 2013; 13: 1503-11. 